\title{
An artist of the floating world
}

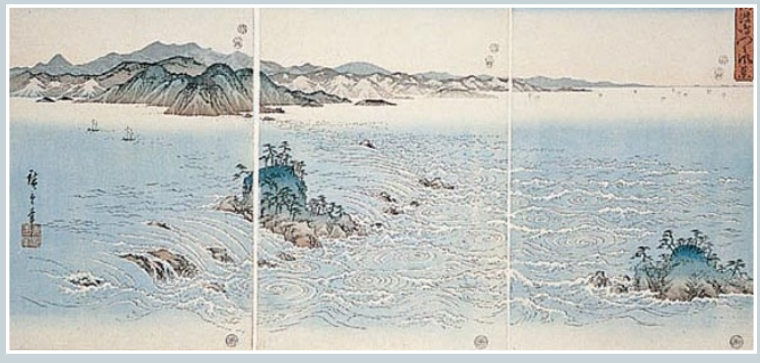

This triptych, Landscape with the Whirlpools at

Awa, is one of over 140 works by the Japanese master Hiroshige (1707-1858) that feature in an exhibition to celebrate the bicentenary of his birth. The painting is typical of
Hiroshige's work, inspired by the ruggedness and hostility of the region around his home in Edo (presentday Tokyo). An instinctive feeling for the violence of the natural world is also seen in his most famous series of prints, The 53 Stations of the Tokaido Road, in which travellers battle through rain, mist and snow on the arduous journey from Edo to Kyoto. Hiroshige's work inspired many Western painters, particularly the French Impressionists. His prints are considered innovative for the time, and give some insight into a longpast Asian culture. The exhibition, at the Royal Academy of Arts in London, runs until 28 September 1997. Kate McGeown highly selective biological catalyst systems.

However, in an ideal industrial catalyst system, the electron equivalents used for the reductive activation of $\mathrm{O}_{2}$ would come from the target substrate itself. In a rare and muchcited example, Groves and Quinn demonstrated the epoxidation of alkenes by $\mathrm{O}_{2}$ alone, catalysed by a ruthenium-porphyrin ${ }^{5}$. The hindered porphyrin ligand enabled key intermediates, RuOORu and subsequently $\mathrm{Ru}(\mathrm{IV})=\mathrm{O}$ and $\mathrm{O}=\mathrm{Ru}(\mathrm{VI})=\mathrm{O}$, to form, but not $\mathrm{RuORu}$, the usual structural and kinetic deadend species in homogeneous catalysed oxidations. The facility for these reactions precluded significant radical-chain oxidation. $\mathrm{Ru}-$ thenium and other metal-oxo $(\mathrm{M}=\mathrm{O})$ species can participate in nonradical and highly selective reactions. Furthermore, the reactivities (rates and selectivities) of $\mathrm{M}=\mathrm{O}$ species are highly tunable by alteration of the other ligands on the metal centre, which has been accomplished in nature through evolution and in industry through human ingenuity.

An ideal catalyst must also be stable. Virtually all catalysts, from enzymes to synthetic metal complexes and heterogeneous metal surfaces, are subject to degradation during reaction. This leads to a loss in activity or selectivity, or both, often with catastrophic consequences. Homogeneous oxidation catalysts, which can include enzymes, ribozymes and many industrial catalysts, are particularly vulnerable as they contain organic ligands or structures that are thermodynamically unstable under operating (turnover) conditions. Like all organic compounds, the organic components of these catalysts are set up to fail; instability hangs over them like a sword of Damocles.

The generic oxidative instability problem of soluble oxidation catalysts has been solved by using particular derivatives of polyoxometalates (oxidatively resistant $\left(\mathrm{d}^{0}\right)$ clusters of transition-metal cations and oxygen anions $)^{6-9}$. These derivatives are defect structures containing several oxygen atoms that simultaneously hold the metal ion (for example, $\mathrm{Ru}$ in Fig. 1), facilitating and controlling the metal ion's catalytic activity'. Neumann and Dahan ${ }^{1}$ have used a sterically hindered $\mathrm{Ru}$-containing polyoxometalate, $\left\{\left[\mathrm{WZnRu}_{2}(\mathrm{OH})\left(\mathrm{H}_{2} \mathrm{O}\right)\right]\left(\mathrm{ZnW}_{9} \mathrm{O}_{34}\right)_{2}\right\}^{11-}$, that contains a barrier preventing the formation of dead-end MOM species (Fig. 1). This innovative system combines the direct activation of $\mathrm{O}_{2}$ with subsequent selective substrate oxidation similar to the GrovesQuinn system, but with the stability of a polyoxometalate devoid of organic structure.

The precise nature of the oxygenated and active forms of the Neumann-Dahan catalyst and the mechanism of substrate oxidation are not fully elucidated, but this work is a significant step towards the Holy Grail of activating $\mathrm{O}_{2}$ and catalysing selective nonradical oxidations without the consumption of other reagents. The challenges are now to achieve broader applicability (only hydrocarbons are addressed), faster reaction rates and compatibility with a range of reaction conditions.

Craig L. Hill and Ira A. Weinstock are in the Department of Chemistry, Emory University, 1515

Pierce Drive, Atlanta, Georgia 30322, USA.

1. Neumann, R. \& Dahan, M. Nature 388, 353-355 (1997).

2. Sheldon, R. A. J. Mol. Catal. A: Chem. (spec. iss.) 117, 1-489 (1997).

3. Barton, D. H. R., Martell, A. E. \& Sawyer, D. T. (eds) The

Activation of Dioxygen and Homogeneous Catalytic Oxidation (Plenum, New York, 1993).

4. Norrby, P. O., Kolb, H. C. \& Sharpless, K. B. J. Am. Chem. Soc. 116, 8470-8478 (1994).

5. Groves, J. T. \& Quinn, R. J. Am. Chem. Soc. 107, 5790-5792 (1985).

6. Pope, M. T. \& Müller, A. Angew. Chem. Int. Edn Engl. 30, 34-48 (1991).

. Katsoulis, D. E. \& Pope, M. T. J. Am. Chem. Soc. 106, 2737-2738 (1984).

8. Hill, C. L. \& Prosser-McCartha, C. M. Coord. Chem. Rev. 143, 407-455 (1995).

9. Hill, C. L. \& Brown, R. B. J. Am. Chem. Soc. 108, 536-538 (1986).

\section{Daedalus}

\section{A personal thermostat}

The human body is warmed by central heating. The furnace is the metabolizing organs such as the heart, liver and brain. The working fluid is the blood, pumped round the small-bore plumbing of the vascular system.

This arrangement works well in the tropics where it evolved; but in temperate and chilly climates it needs additional insulation (clothes), and even extra heating (fire). Even so, people with poor circulation often suffer from cold hands and feet.

Daedalus has an upgrade.

He points out that blood contains both the fuel (glucose) and the oxidant (oxygen) for metabolic heating. In principle, it could generate heat by reaction wherever it is needed. In this connection he recalls an old scheme of his for countering alcoholism. A suspension of microspheres, coated with a set of immobilized alcohol-oxidizing enzymes, was injected into the subject's bloodstream. When he drank alcohol, they burnt it up as fast as it entered his blood. They replaced a pleasant intoxication by a sweaty fever.

Suppose, says Daedalus, the microspheres carried an enzyme system which oxidized not alcohol but glucose. By itself this would be a disaster. The body would burn all its fuel to heat, leaving none for anything else. But heat reversibly denatures some enzymes. It unwinds their protein chains a little, switching them off. So DREADCO biochemists are studying the oxidative biochemistry of lizards, molluscs, insects, and similar cold-blooded creatures. With luck, one of them will deploy a glucose-oxidizing enzyme which works well enough in the cold, but is reversibly denatured at $37^{\circ} \mathrm{C}$ - human body temperature. Immobilized on microspheres and injected into the bloodstream, the enzyme will be inert and harmless in the core regions of the body. But at the cold skin surface of an exposed extremity, it will renature. It will burn glucose until the blood around it has reached $37^{\circ} \mathrm{C}$, when it will be switched off again. In effect, it will act as a perfect distributed body thermostat.

A DREADCO 'Warm Glow' injection should last for ages. The immobilized enzyme will be inaccessible to the immune system, and will degrade only slowly. The user will feel warm in the coldest conditions and the most provocative clothing. He or she will spend nothing on fuel, but a lot more on food - all of which will be burnt up in keeping warm. Even the greediest user will never get fat.

\section{David Jones}

